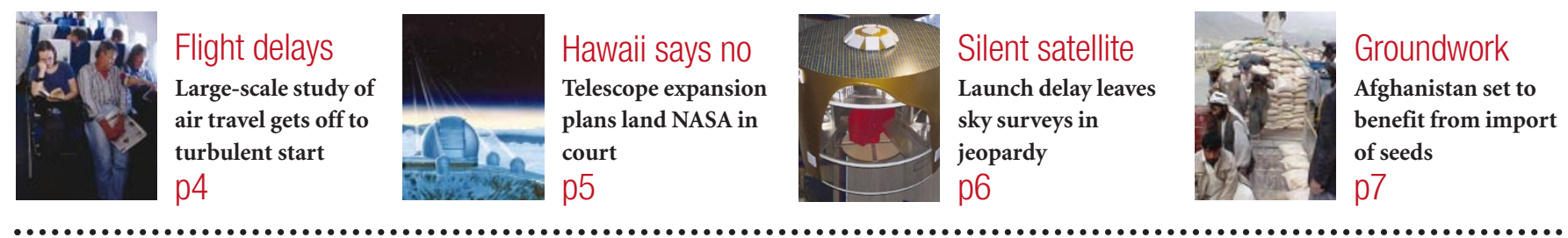

\title{
Venter lays foundations for fresh career as ethical philanthropist
}

\section{Declan Butler}

Bioethics and ecology are the new watchwords for the man behind the privately funded sequence of the human genome.

Craig Venter, who stepped down in January after three years as president of Celera Genomics, the biotechnology company in Rockville, Maryland, says he plans to devote his immediate future to running a new foundation also based in Rockville.

He has announced the creation of the not-for-profit J. Craig Venter Science Foundation. This will support The Institute for Genomic Research (TIGR) - the existing research operation run by Venter's wife, Claire Fraser - and two new institutes, the TIGR Center for the Advancement of Genomics, a bioethics think-tank, and the Institute for Biological Energy Alternatives.

"I'm delighted to be out of the business world, and I'm much happier being back in the basic science not-for-profit world where I'm free to speak out without worrying about

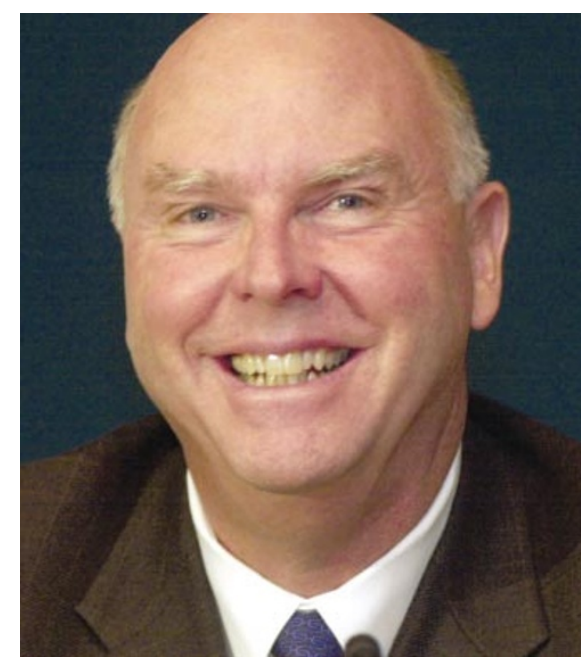

Profit-shy: Craig Venter wants to concentrate on renewable energy and the ethics of genetics.

offending shareholders or those with vested interests," Venter says. The endowment

\section{Weapons lab's top job left unfilled}

\section{Rex Dalton, San Diego}

The Lawrence Livermore National Laboratory in California is facing a leadership void after the University of California was forced to abandon its plans to appoint the facility's next director.

The university, which manages the nuclear-weapons laboratory for the Department of Energy, had planned to announce the appointment of Ray Juzaitis, an associate director of the Los Alamos National Laboratory in New Mexico, at a press conference on 26 April, sources say.

But university president Richard Atkinson cancelled the announcement after a last-minute intervention by the energy department. This dramatic reversal sparked fierce speculation in Washington and California about the delay. Atkinson had briefed Spencer Abraham, the energy secretary, a few days earlier, and received approval for the candidate, a university spokesman says. The fact that Juzaitis ran the nuclearweapons physics division at Los Alamos where Wen Ho Lee, the engineer accused and then acquitted of spying at the New Mexico laboratory, had worked - has been leaked to the press as a possible reason for the delay.

But the belated arrival of the Lee issue in the process is seen by some observers as a ruse by senior staff at Livermore to undermine the appointment of a director from Los Alamos, the other US nuclearweapons laboratory, with which Livermore has always enjoyed a strained relationship.

University officials are now considering how best to proceed with the appointment. In addition to Juzaitis, sources say, three other candidates had been in contention for the job: Michael Anastasio and Jeffrey Wadsworth, both deputy directors at Livermore, and Steve Koonin, provost of the California Institute of Technology. reportedly kicks off with $\$ 100$ million of Venter's own money.

The bioethics think-tank will assess issues such as genetic privacy, discrimination, the genetics of ethnicity and stem cells, and will have a public-outreach and educational component. Venter claims that the availability of the human genome sequence is fuelling a resurgence in the view that genes can determine all aspects of human behaviour, and says that the think-tank will try to untangle what is deterministic and what is not.

The Institute for Biological Energy Alternatives will research clean energy sources and the sequestration of carbon dioxide, Venter says. It will use microbial genomics to engineer metabolic pathways that could generate microbes with enhanced capacities for producing hydrogen and fixing carbon dioxide.

In his spare time Venter says he plans to "spend some time examining my own genetic code". He has revealed that he was one of the six supposedly anonymous donors used to generate Celera's genome sequence. The published sequence is a composite, but Venter says he has access from the Celera database to his own genome.

Not everyone is amused by the revelation. Arthur Caplan, a bioethicist at the University of Pennsylvania, and member of Celera's scientific advisory board, says it is "not unethical, but a disappointment to me. My hope was that the genome would be seen as something that all of humanity both owned or could claim".

Whatever Venter's future now holds, it may be brighter than that of the company he created. Celera's share price has plummeted over the past two years from a March 2000 high of $\$ 247$ to $\$ 15$.

Celera last month abandoned its goal of selling genetic information, focusing instead on drug discovery (see Nature 416,778;2002). Analysts say that the free availability of genome databases in the public domain means that commercial ones are less lucrative than they were once touted to be. And, to judge by Celera's stock performance since its new business plan and president were announced on 22 April, investors are sceptical of its ability to compete in drug discovery. 